\title{
The company human capital basis in the context of career component
}

\author{
Olena Sushchenko ${ }^{11}$, Karyna Tymoshenko ${ }^{1}$, Volodymyr Yermachenko $^{1}$, Serhii Sushchenko ${ }^{1}$ \\ ${ }^{1}$ Department of Tourism, Simon Kuznets Kharkiv National University of Economics, Kharkiv, \\ Ukraine
}

\begin{abstract}
An industrial enterprise is a complex mechanism, the stability and efficiency of which depends on the influence of many factors, the main among which is the provision of an enterprise with production personnel with appropriate education, qualification level, skills and experience. Consequently, investing in personnel development creates conditions for expanding their competencies in order to ensure the competitiveness of personnel and a high level of enterprise performance. It is precisely the inadequate professional skills of the staff of most enterprises that cause low productivity, lead to significant shortcomings in the system of labour organization and management, and as a result - inefficient work of the enterprise. On the information analytical basis, the concept of a new approach to professional development is formulated as the mutual responsibility of the employee and the organization.
\end{abstract}

\section{Introduction}

In the current economic conditions, a new generation of workers are formed and begins to dominate, so called knowledge workers. "As evidenced by the data of the Organization for Economic Cooperation and Development (OECD), in the member countries of this organization, since the $1960 \mathrm{~s}$, they have steadily increased (on average, $3 \%$ of the annual investment in knowledge (science, education, public and private education and software). So, between 1985 and 1992 in the OECD member countries spent on knowledge-related investments on average from 8 to $11 \%$ of their GDP. In 1998, their total investments in knowledge reached $8.8 \% "$ " [1].

In other words, the transformation of the economic system and society as a whole under the influence of scientific, technical and informational revolutions leads to the need to form a completely different type of worker. Under these conditions, an employee's characteristics such as creativity, ability to innovate, a high degree of adaptation to production technologies, ability to make quick decisions, etc., come to the fore. That is, employees are not only highly qualified professionals, but also have developed creative intelligence any working conditions and their changes, as well as a rapid change of profession, cultural and social environment, self-knowledge and self-improvement.

\footnotetext{
${ }^{1}$ Corresponding author: helen.sushchenko@gmail.com
} 
Thus, the process of human capital development involves qualitative changes in it, which are provided by professional (professional development, retraining, etc.), social (improvement of working conditions, team relations, organizational culture, etc.) and career growth. Since the proportion of the last component in practical activities is insignificant compared to others, attention should be focused on the first two.

\section{The main components of human capital development}

It should be noted that with the change in technological modes, the very content of labour also changes, it is increasingly becoming intellectual, innovative, and creative. E. Toffler in the mid-80s noted that most "third wave" companies no longer increase their income by "squeezing sweat" from their employees; the main value acquired information and creativity [2]. According to V. Inozemtsev, at the beginning of the 21 st century, the proportion of intellectual workers in the US was $70 \%$ of the total workforce, with knowledge itself becoming the object of knowledge [3].

Because of the effective use of productive abilities of the subjects of the formation of human capital, the maximum development of the latter occurs. In view of the above, we can assert that a person is able to manage his development in the appropriate limits, applying precisely the abilities that are most needed in this case. It is important not only the volume of knowledge and abilities, but also the ability to use them.

Consequently, the achievement of a high level of efficiency of production and economic activity is possible only with the condition of ensuring a continuous and intensive process of qualitative accumulation, increase and preservation of human capital in the form of professional knowledge, skills and abilities of employees of the enterprise.

In the study of human capital development it is expedient to consider three of its components, namely: professional development; social development; career development. Professional development of personnel is a system of interrelated activities, which include the development of strategy, forecasting and planning of staffing requirements, career management and professional growth, the organization of the process of adaptation, training, and the formation of organizational culture. Professional development also influences the employees themselves. By developing their skills and acquiring new skills and knowledge, they become more competitive in the labour market and receive additional opportunities for professional growth both inside and outside of their organization. This is especially important in today's conditions of rapid aging of professional knowledge.

Social development involves the improvement of forms, methods and conditions of life of workers based on changes in their development, the growth of social activity of staff, the growth of the effectiveness of the enterprise, the growth of material well-being of staff. The conditions that ensure the social development of workers include the compliance of each employee's personal capabilities with the structure and content of his activities, the similarity of employees 'moral positions, the homogeneity of the main motives of activities and individual goals of team members, the possibility of real complementarity and the organic combination of employees' abilities collective [4].

Career growth of human capital is the personal contribution of each employee to the overall workforce planning process in an enterprise in order to improve the skills and qualification of employees.

Career growth is necessary to create a successful career program, which includes the desire to develop and promote employees within the organization, the formation and support of a positive image of the employer. To do this, it is necessary to create a special personnel service in the enterprise the specialists of which will be responsible for providing tools and information that can help in making career decisions. They should also help managers create a climate and culture that should foster growth and stimulate professional 
development. Employees, in turn, should take advantage of this climate and gain knowledge about the important components of career planning.

So, career development of personnel is a process that requires employees and organizations to partner, which expands the knowledge, skills and abilities needed to solve current and strategic tasks and, as a result, to improve the abilities of employees and at the same time update the organization and improve the efficiency of its activities [5].

\section{Career planning by providing labour resource development services (LRDS)}

So how to plan a career? LRDS specialists are responsible for providing tools and information that can help in making career decisions. They should also help managers create a climate and culture that is conducive to growth and stimulate professional development. They need to develop career realization plans, analyze potential career paths, and determine whether employees have the skills, abilities, and knowledge necessary to be placed in appropriate positions. Just as in career planning, LRDS specialists are also responsible for developing and providing tools for acquaintance with a career - choosing career analysis tools, assisting in transitioning from performance evaluations to assessing development, helping managers and employees in developing growth and development plans and managing reorientation of the organization to the culture of development. As a result, employees, managers and specialists of LRDS become equal partners in career awareness activities.

Career planning is the personal contribution of the employee to the overall process of planning the company's workforce. Thus, career planning is a procedure for identifying individual career goals and developing measures for their implementation. It can also be regarded as a personal process consisting of three criteria:

1) planning of life is carried out to unite career and life;

2) development planning is used to improve the skills and qualifications of employees;

3) performance planning is used to increase productivity and organizational efficiency.

Target career planning is essential for creating a successful career program. The organization, through the LRDS, should stimulate employees and assist them in their own career planning.

There are several reasons to use career planning programs:

- The desire to develop and promote employees within the organization;

- Lack of potential talent;

- Desire to contribute to career planning;

- Strong interest of employees;

- Desire to increase productivity;

- Personal interest of department heads;

- Formation and maintenance of a positive image of the employer.

Any of the above points is an important reason for organizations to support and stimulate career-planning efforts. Moreover, LRDS specialists must understand that any or all of these reasons may be present in their organization. Regardless of the number of reasons for career planning, the main task of LRDS specialists remains unchanged: the development of labour resources within the organization [6]. This includes developing as well as moving up the career ladder using career planning. All this, of course, implies the growth and development of employees in the interests of the organization. However, in the practice of career planning programs, barriers may arise:

1) insufficiently clear distribution of roles in the organization in the field of career planning responsibilities; 
2) lack of qualified LRDS specialists involved in career planning and similar processes;

3 ) the organization's underestimation of the importance of career planning.

The organization needs to introduce some kind of career planning philosophy, consider organizational development procedures, including the duties of LRDS specialists and managers, additional training and a long-term commitment.

Career planning tasks is to provide employees necessary knowledge about themselves and the surrounding reality. Career planning techniques include counselling, seminars, selfhelp materials, professional information and assessment programs. Although employees are fully responsible for their careers, the organization is their equal partner in career planning. Therefore, the main goal of career planning activities is to encourage employees to be accountable in this matter [7].

Informing staff about the company's long-term plans and strategies creates the prerequisites for employee career planning, since it gives an idea of new career opportunities, the needs of the organization in new competencies.

Today, many factors contribute to the introduction of career planning programs that are supported by the organization:

1) innovative processes in technique, technology, management;

2) talented employees who are waiting for opportunities for career advancement;

3 ) corporate growth and development leading to the need for more skilled labour;

4) a global competitive environment that requires more and more knowledge from employees;

5) outsourcing, staff reduction and optimization of organization size;

6) recognizing that employees are the most valuable asset of an organization.

Professional development programs can be significantly expanded if LRDS specialists use the five-step approach (Table 1).

Table 1. A five-step approach to professional development

\begin{tabular}{|l|l|l|}
\hline Step & Employee actions & Organization actions \\
\hline 1. Orientation & Career responsibility & $\begin{array}{l}\text { Individual conversation or } \\
\text { seminar for new employees }\end{array}$ \\
\hline $\begin{array}{l}\text { 2. Identification of his } \\
\text { position }\end{array}$ & Analysis of own career & Manager as a career adviser \\
\hline 3. How am I treated? & Self-examination & Performance evaluation \\
\hline $\begin{array}{l}\text { 4. What are my } \\
\text { options? }\end{array}$ & $\begin{array}{l}\text { Acquaintance with the } \\
\text { organization. Using } \\
\text { Career Resource Centres }\end{array}$ & $\begin{array}{l}\text { Vacancy announcements. } \\
\text { Career Resource Centres. } \\
\text { Workforce planning }\end{array}$ \\
\hline $\begin{array}{l}\text { 5. How will I achieve } \\
\text { my goal? }\end{array}$ & Career planning & $\begin{array}{l}\text { Manager in the role of career } \\
\text { adviser. Career planning }\end{array}$ \\
\hline
\end{tabular}

The process begins with the identification of employee orientation, during which the focus is on individual career responsibility. To do this, it is advisable to hold a seminar - a business game, during which the participants' abilities, interest in career growth and the interest of participants in achieving the goals of the organization are well manifested. This allows you to identify ways to achieve a balance of personal and corporate interests. Another way to achieve greater unity involves the use of a manager - a direct manager (as a career adviser) to express and convey the idea that professional development is primarily an employee's responsibility [8].

The second stage is calling individual self-analysis. At this stage, the employee answers the question "Who am I?" The main goal here is to get familiar with the career. A manager as a career adviser and using surveys can help identify interests, values, and abilities related to professional development. 
Stage three is authentication. The employee defines "How am I treated?" in the organization. Development assessments are key events that organizations use to provide feedback to staff on these issues. At this stage, it is necessary to determine the opportunities available to the employee. Employees gain knowledge about the organization and seek alternatives inside or outside the organization by participating in growth and development activities.

At the fourth stage, LRDS specialists reveal the organization's resource planning needs so that employees can determine how well they fit their organization. LRDS specialists should also encourage employees to study announced vacancies. In addition, mentors and managers (as career advisers) should also express their views on career opportunities.

Finally, at the fifth stage, employees should turn their attention to developing an action plan to achieve career goals. Career planning is the main activity at this final stage. At the same time, LRDS specialists should be involved in the training and engagement of managers as career advisors to help employees draw up career plans.

To ensure the success of joint efforts of employees and organizations, an important role is played by the corporate culture, the tasks of the management and the team is to form it as a culture of development. In practice, a culture of development cannot succeed unless leaders, managers and employees collectively use their abilities to achieve strategic business goals and objectives. Improper handling of labour resources impedes obtaining the desired results.

Organizational performance and effectiveness cannot be achieved without improving the skills, qualifications, talents and intellectual abilities of all participants in the organization. It is important to organize personnel work in such a way as to ensure the solution of the tasks of the innovative development of enterprises. The problem of career growth of employees should be addressed in the aspect of the formation of innovative personnel to ensure sustainable competitiveness [9].

\section{Results and Discussion}

Staff development is a process that requires from employees and the organization of such a partnership that broadens the knowledge, skills, abilities and settings needed to solve current and strategic tasks. Professional development is the quintessence of the whole progress of the organization - the improvement of employees' abilities, while at the same time updating the organization and increasing the efficiency of its activities. Human capital must fully comply with the organization's strategy. Such an approach fundamentally changes the function of labour resources and focuses on the work of HR managers on the development of the profile of competencies of employees, assessment of the readiness of human capital to implement the strategy of the enterprise. At the same time, the existence of such an approach is the basis for the development of human capital development programs designed to increase the degree of strategic readiness for implementation of the strategy.

\section{References}

1. D.A. Ashirov, O.YU. Leonova Upravleniye chelovecheskimi resursami (Moscow, MMIEIFP, 2003)

2. Ye. Toffler Tretya khvilya (Kyiv, VD "Vsesvít", 2000)

3. V. Inozemtsev V poiskakh razumnoy strategii Inozemtsev, Econ. i MO, 7, 124-128 (2006) 
4. O. A. Sushchenko Development of employment mediation services and labour market in the tourism industry in Ukraine (Riga: "Landmark" SIA, 104-114, 2016)

5. N. Nenkov, O. Sushchenko, Y. Dyachenko Role of chief information officer within the system of human resource development in the service organizations (tourism). Economic Annals-XXI, 165, 97-103 (2017)

6. I.A. Esaulova, Perm: Izd-vo Permskogo gos. tekhnicheskogo un-ta, 11, (2009)

7. M. Petrova, M. Tepavicharova, L. Boykova Possibilities for human capital development in the mining and quarrying sector in Bulgaria. E3S Web of Conferences, 41. Retrieved from: https://doi.org/10.1051/e3sconf/20184104017 [available on 6 May 2019] (2018)

8. Jerry W.Gilley, A. Steven, Eggland and Ann Maycunich Jilley. Principles of Human Resource Development. Second edition. (Cambridge, Perseus Publishing, 2002)

9. K.V. Timoshenko Globalní ta natsíonalní problemi ekonomíki, 19, 271-275 (2017)

10. I.M. Trunina Development of entrepreneurship entity competitive strategy using competence-based approach. Actual Problems of Economics, 3(177), 191-198 (2015)

11. C. Koch The big uneasy, CIO Magazine, Vol. 11, 40-47, (1997) 